\title{
ROBERT POKLEK
}

ORCID: 0000-0002-4727-8806

Uniwersytet im. Adama Mickiewicza w Poznaniu

poklek@interia.pl

\section{Motywacja zawodowa funkcjonariuszy rozpoczynających pracę w więziennictwie}

https://doi.org/10.19195/2083-7763.10.17

\section{Abstrakt}

Służba Więzienna jest grupą dyspozycyjną, a sam zawód funkcjonariusza więziennego obarczony wieloma trudnościami wynikającymi ze specyfiki środowiska instytucji totalnej, zagrożeń ze strony więźniów oraz niezbyt wysokim prestiżem i szacunkiem społeczeństwa. Nasuwa się pytanie, jakimi motywami kierują się osoby podejmujące decyzję o wstąpieniu do służby i zawodowe związanie się $\mathrm{z}$ więziennictwem. W opracowaniu zaprezentowano badania własne z zakresu struktury motywacji zawodowej przeprowadzone wśród nowo przyjętych funkcjonariuszy w latach 2012 oraz 2017. Oprócz analizy natężenia kierunków motywacji dokonano porównań pomiędzy grupami funkcjonariuszy przyjętych w roku 2012 i 2017, biorąc pod uwagę przemiany społeczno-ekonomiczne zaistniałe w ciągu pięciu lat, a zwłaszcza zmiany ustawy emerytalnej funkcjonariuszy służb mundurowych.

Słowa kluczowe: Służba Więzienna, grupy dyspozycyjno-mundurowe, motywacja, motywacja zawodowa, inwentarz motywów podejmowania pracy

\section{Instytucja więzienia i zagrożenia w pracy funkcjonariuszy Służby Więziennej — wprowadzenie w problematykę}

Prawidłowe funkcjonowanie państwa i zapewnienie bezpieczeństwa jego obywatelom wymaga od jego rządzących powoływania szeregu instytucji, które stałyby na straży praworządności i chroniły społeczeństwo przed różnymi zagrożeniami. Część z tych instytucji może z mocy prawa ograniczać prawa jednostek w imię wyższych celów, a nawet izolować niektórych obywateli od reszty społeczeństwa. Do takich instytucji należy więziennictwo, którego celem jest wykonywanie postanowień sądu (tymczasowe aresztowanie lub kara pozbawienia wolności), a misją 
społeczną jest zadośćuczynienie sprawiedliwości społecznej, ochrona społeczeństwa przed sprawcami przestępstw oraz przywracanie społeczeństwu wartościowych jednostek (resocjalizacja i readaptacja społeczna) ${ }^{1}$.

W myśl ustawy o służbie więziennej Służba Więzienna jest umundurowaną i uzbrojoną formacją apolityczną podległą Ministrowi Sprawiedliwości charakteryzującą się własną strukturą organizacyjną. W skład struktury organizacyjnej wchodzą zakłady karne i areszty śledcze, oddziały zewnętrzne zakładów lub aresztów, okręgowe inspektoraty Służby Więziennej, Centralny Zarząd Służby Więziennej. Szkolenie funkcjonariuszy odbywa się w Centralnym Ośrodku Szkolenia Służby Więziennej w Kulach, ośrodkach szkolenia Służby Więziennej w Suchej i Olszanicy oraz w Wyższej Szkole Kryminologii i Penitencjarystyki. Paramilitarny charakter Służby Więziennej nadaje jej formalną strukturę organizacyjną, zbliżoną do wojskowej. Sposób realizacji zadań jest ściśle określony przepisami i instrukcjami odnoszącymi się do poszczególnych stanowisk służbowych. Miejsce w hierarchii wyznacza funkcjonariuszom przynależność do właściwego korpusu (podoficerów, chorążych, ewentualnie oficerów) i odpowiedni stopień oraz zajmowane stanowisko. Podległość służbowa na wzór wojskowy skutkuje wyłączeniem Służby Więziennej spod wpływów obowiązywania kodeksu pracy, a wciąga w orbitę zależności służbowych regulowanych pragmatykami zawodowymi na wzór policji i wojska. Według stanu na dzień 31 grudnia 2018 r. służbę pełniło 27286 funkcjonariuszy, w tym 5282 kobiety. Na stanowiskach oficerskich zatrudnionych było 7979 funkcjonariuszy, na chorążych - 3866 i na podoficerskich -15 441. Ponad $60 \%$ funkcjonariuszy legitymuje się wyższym wykształceniem ${ }^{2}$.

Istotą funkcjonowania więzienia - niezależnie od misji i celów Służby Więziennej - jest izolowanie ludzi (podejrzanych lub sprawców przestępstw) od reszty społeczeństwa. Więziennictwo jest zatem specyficzną organizacją społeczną, którą Erving Goffman zaliczył do instytucji totalnych ${ }^{3}$. Rzeczywistość kreowana przez więzienie staje się zupełnie innym światem, odrębnym, z uwagi na bariery architektoniczne i izolację społeczną, od rzeczywistości funkcjonującej poza instytucją — w świecie ludzi wolnych. Miarą totalności więzienia jest stopień izolacji więźniów od społeczeństwa i ograniczenia możliwości dokonywania przez nich wyborów i podejmowania samodzielnych decyzji, czyli poziom przejęcia przez instytucję kontroli nad czasem i przestrzenią, w której funkcjonują więźniowie, zaanektowania większości sfer życiowych według zaplanowanego administracyjnie harmonogramu dnia ${ }^{4}$.

\footnotetext{
${ }^{1}$ R. Poklek, Stużba Więzienna w systemie bezpieczeństwa państwa, „Securitologia” 1 (17), 2003, s. $163-164$.

${ }^{2}$ Roczna informacja statystyczna za rok 2018, Ministerstwo Sprawiedliwości, Centralny Zarząd Służby Więziennej.

${ }^{3}$ E. Goffman, Instytucje totalne. O pacjentach szpitali psychiatrycznych i mieszkańcach innych instytucji totalnych, Sopot 2011, s. $13 \mathrm{n}$.

${ }^{4}$ R. Poklek, Instytucjonalne i psychospołeczne aspekty więzienia, Kalisz 2010, s. 36-37.
} 
To wyznaczenie przez instytucję administracyjnych ram funkcjonowania, ról i pozycji zajmowanych w strukturze (osadzony versus funkcjonariusz), zakres kompetencji, praw i obowiązków sformułowanych w regulaminach i innych przepisach oraz wiele procedur wyznaczających zadania hierarchicznie usytuowanego personelu zbliża więzienie do weberowskiej instytucji biurokratycznej ${ }^{5}$. Instytucja taka podporządkowuje swoją działalność instrumentalnej efektywności, czyli racjonalnemu nakładowi środków i minimalizowania kosztów w stosunku do uzyskiwanych rezultatów. Urzędy i stanowiska są wieloszczeblowe i rozlokowane hierarchicznie, każdy szczebel wiąże się z zakresem przywilejów i uprawnień, co przekłada się na zarobki i prestiż. Istnieje tu daleko posunięta specjalizacja i podział funkcji, co z kolei przekłada się na zakres kompetencji w stosunku do przełożonych (kierownictwa), współpracowników i podwładnych. Wpływa to na depersonalizację stosunków międzyludzkich, pozbawienie ich elementów osobistych, emocjonalnych i intymnych, a koncentrowanie się na celach instytucji i bieżących zadaniach. Rekrutacja do pracy i awans zawodowy oraz ewentualne nagrody dla urzędników są ściśle skodyfikowane. Wreszcie, każda decyzja, działanie, podjęta i wykonana decyzja jest zarejestrowana i zarchiwizowana ${ }^{6}$. Praca penitencjarna przybierająca formę urzędową polega na formalnym i proceduralnym realizowaniu przepisów dotyczących wykonywania zadań więziennictwa oraz obowiązków funkcjonariuszy na każdym stanowisku służbowym i egzekwowaniu poleceń wydawanych więźniom. Każde odstępstwo od założeń idealnej instytucji biurokratycznej, a w przypadku więzienia odstępstwo od regulaminów i procedur, wiąże się z nieskutecznością prowadzonych działań i dysfunkcją instytucji, przyjmując formę patologii, czyli biurokratyzacji ${ }^{7}$.

Niemniej na sformalizowaną instytucjonalnie strukturę pozycji i ról nakłada się układ grup nieformalnych powstających zarówno wśród więźniów, jak i funkcjonariuszy $^{8}$. Wewnętrzną organizację więzienia stanowi złożony schemat stosunków interpersonalnych mających głównie na celu utrzymanie status quo pomiędzy funkcjonariuszami a osadzonymi oraz względnego spokoju wśród więźniów. Personel zostaje wyposażony w definicje i skrypty rzeczywistości więziennej, a w szczególności poglądy na temat postaw podopiecznych, ich zachowań pozytywnych i dewiacyjnych, zgodnie z którymi stygmatyzuje ich do tego stopnia, że tracą oni w jego oczach indywidualną tożsamość. Podobne zjawisko występuje u samych funkcjonariuszy, którzy po pewnym czasie identyfikują się z rolą strażnika więziennego. Można to potraktować jako specyficzną współzależność między organizacją społeczną a doświadczeniem

${ }^{5}$ J.H. Turner, Socjologia: koncepcje i ich zastosowanie, Poznań 1998, s. 109.

${ }^{6}$ P. Sztompka, Socjologia. Analiza społeczeństwa, Kraków 2007, s. 126-128.

7 S. Grzesia, Biurokracja i biurokratyzacja w pracy penitencjarnej wychowawców, [w:] Blaski i cienie współczesnej przestrzeni penitencjarnej. Człowiek a system, red. P. Stępniak, Kalisz 2014, s. $180-181$.

${ }^{8}$ A. Krukowski, Socjologia zakładu karnego (podstawowe zagadnienia), [w:] Problemy współczesnej penitencjarystyki w Polsce, red. B. Hołyst, Warszawa 1984, s. 43-55. 
jednostkowym ${ }^{9}$. Ta dwuczłonowa społeczność więzienna skutkuje polaryzowaniem się postaw, antagonizmem, wrogością, całkowitym brakiem zaufania obydwu stron, co stanowi przyczynę interakcji konfliktu. Konfliktom w więzieniu często towarzyszą zachowania agresywne mające na celu wyrządzenie krzywdy lub spowodowanie szkody, a prezentowana przez więźniów agresja może stanowić cel sam w sobie lub być agresją instrumentalną służącą do osiągnięcia innego celu ${ }^{10}$. Nie bez znaczenia jest zjawisko tworzenia się alternatywnej do obowiązującej kultury, czyli podkultury więziennej, która zawsze będzie nastawiona negatywnie do administracji więzienia i formalnych norm funkcjonowania ${ }^{11}$.

Kolejnym negatywnym skutkiem pracy w więzieniu jest obcowanie z więźniami dysfunkcyjnymi, podejmującymi patologiczne zachowania to jest próby targnięcia się na własne życie (czasami skuteczne), samouszkodzenia ciała (niekiedy bardzo drastyczne), skrajny brak higieny (do celowego brudzenia się ekskrementami włącznie), demolowanie pomieszczeń zakładu lub aresztu, wszelkie formy agresji i przemocy kierowanej zarówno na współosadzonych, jak i personel. Funkcjonariusze narażeni są na szantaż, prowokacje korupcyjne, groźby, słowne ataki i napaść fizyczną, muszą interweniować w sytuacji zagrożenia życia lub zdrowia innych osób oraz gdy niszczone jest mienie jednostki. Przekłada się to na poczucie permanentnego zagrożenia własnego i swojej rodziny i wzmaga stres zawodowy. Dodatkowo niska efektywność resocjalizacyjna, często nie z winy personelu, bezsilność wobec biurokracji i przedkładania interesu instytucjonalnego nad indywidualny, uwikłanie w życie osobiste więźniów i towarzyszenie im w trudnych decyzjach, mogą wywoływać u niektórych osób syndrom wypalenia zawodowego ${ }^{12}$.

Czynnikiem wpływającym na problemy z tożsamością zawodową więzienników, przez co podnoszącym dodatkowo trudność funkcjonowania zawodowego jest to, że zawód funkcjonariusza służby więziennej jest mało poznany w społeczeństwie i dlatego nie cieszy się prestiżem. Więziennictwo, niczym relikt dawnej epoki, nadal jawi się opinii publicznej jako hermetyczne i izolujące się środowisko. Mimo deklarowanej otwartości więzień, kontroli społecznej nad wykonywaniem wyroków sądowych oraz obecności przedstawicieli więziennictwa na oficjalnych uroczystościach państwowych i lokalnych imprezach o życiu więziennym społeczeństwo wie niewiele, a dowiaduje się zazwyczaj w przypadku ujawnionej afery

${ }^{9}$ R. Poklek, Motywacja osiagnięć funkcjonariuszy Stużby Więziennej, Kalisz 2015, s. 38.

${ }^{10}$ K. Jędrzejak, Konflikty w izolacji więziennej, [w:] Problemy więziennictwa u progu XXI wieku, red. B. Hołyst, S. Redo, Warszawa-Wiedeń-Kalisz 1996, s. 345.

${ }^{11}$ S. Przybyliński, Podkultura więzienna. Wielowymiarowość rzeczywistości penitencjarnej, Kraków 2005, s. 23 n.

12 R. Poklek, A. Piotrowski, Stres zawodowy personelu więziennego pionu ochronnego i wychowawczego, [w:] Metodologiczne problemy w badaniach grup dyspozycyjnych, red. J. Maciejewski, M. Stochmal, Wrocław 2014, s. 381 n.

Forum Socjologiczne 10, 2020

(C) for this edition by CNS 
lub skandalu, na przykad korupcji funkcjonariuszy ${ }^{13}$, ucieczki ${ }^{14}$, samobójstwa więźnia medialnego ${ }^{15}$ albo zabójstwa dokonanego przez skazanego podczas przepustki lub warunkowego zwolnienia ${ }^{16}$. Nie bez winy są tutaj media, które, często w jednostronnej oprawie, prezentują więziennictwo wyłącznie przez pryzmat negatywnych zjawisk, pomijając lub przekłamując pozytywne działania tej instytucji i jej urzędników ${ }^{17}$. Postrzegany jest także jako kategoria tak zwanych brudnych zawodów (dirty works) które, mimo iż są niezbędne do prawidłowego funkcjonowania państwa, nie są darzone szacunkiem przez społeczeństwo. Tak jakby przez samo przebywanie z osobami z marginesu w miejscu odosobnienia sprawiało, że stają się „skażeni materiałem, z którym mają kontakt”" ${ }^{8}$. To sprawia, że zawód więziennika jest jednym z ostatnich wybieranych przez studiującą młodzież podczas badania ich preferencji zawodowych ${ }^{19}$ oraz cieszy się stosunkowo małym zaufaniem społecznym, a jest to spowodowane niewiedzą na temat specyfiki instytucji penitencjarnej i informacji o rzeczywistych celach jej funkcjonowania ${ }^{20}$. O funkcjonariuszach więziennictwa mówi się często, że zainteresowani są wyłącznie zarobkiem i wcześniejszą emeryturą ${ }^{21}$, nie wykazując przy tym aspiracji do szukania innej - w domyśle - bardziej wymagającej pracy, co jest ewidentnie krzywdzącą opinią. Z badań wynika, że oprócz motywów materialnych wśród funkcjonariuszy występuje

13 A. Siemaszko et al., Społeczna percepcja zagrożeń korupcyjnych w Polsce, [w:] Korupcja i antykorupcja. Wybrane zagadnienia. cz. 3, red. J. Kosiński, K. Krak, A. Koman, Warszawa 2012, s. 22.

${ }^{14}$ Uciekinier z pomorskiego więzienia zatrzymany w Szczecinie, https://www.fakt.pl/wydarzenia/ polska/trojmiasto/39-latek-uciekl-z-wiezienia-w-czarnem-zatrzymano-go-w-szczecinie/7f615j6 (dostęp: 21.07.2019).

15 Kolejne samobójstwo więźnia w Białołęce. Powód - zespółabstynencyjny, https://www.tvp.info/ 33647434/kolejne-samobojstwo-wieznia-w-bialolece-powod-zespol-abstynencyjny (dostęp: 21.07.2019).

${ }^{16}$ Morderstwo na przepustce z więzienia. Nie żyje kobieta i dziecko, https://www.tvp.info/38913425/ morderstwo-na-przepustce-z-wiezienia-nie-zyje-kobieta-i-dziecko (dostęp: 21.07.2019).

${ }^{17}$ L. Urbanowicz, Wizerunek służby więziennej w środkach masowego przekazu, [w:] Służba więzienna wobec problemów resocjalizacji penitencjarnej, red. W. Ambrozik, P. Stępniak, PoznańWarszawa-Kalisz 2004, s. 255 n.

18 R. Poklek, Misja i zadania Stużby Więziennej a jej wizerunek i prestiż w społeczeństwie, [w:] Grupy dyspozycyjne wobec zagrożeń bezpieczeństwa państwa, red. J. Maciejewski, M. Stochmal, Z. Ludziejewski, Wrocław 2016, s. $230 \mathrm{n}$.

19 A. Piotrowski, Medialny wizerunek Stużby Więziennej, „Przegląd Więziennictwa Polskiego”, 67-68, 2010, s. 87.

${ }^{20}$ Badanie opinii publicznej na temat wizerunku wymiaru sprawiedliwości, oceny reformy wymiaru sprawiedliwości, aktualnego stanu świadomości w zakresie alternatywnych sposobów rozwiązywania sporów oraz praw osób pokrzywdzonych przestępstwem. Raport z badań, IBC Group \& Homo Homini, Warszawa, luty 2009, s. 15 n.

${ }^{21}$ R. Poklek, Motywacja do pracy $i$ doskonalenia zawodowego personelu więziennego w ujęciu dwuczynnikowej koncepcji motywacji-higieny F.I. Herzberga, Kalisz 2012, s. 16.

Forum Socjologiczne 10, 2020

(C) for this edition by CNS 
także motywacja pozafinansowa ${ }^{22}$, a u niektórych nawet prospołeczna ${ }^{23}$. Należy także nadmienić, że w ciągu ostatnich lat zmieniły się warunki pracy w służbach mundurowych - funkcjonariuszom podwyższono minimalny staż umożliwiający wcześniejsze przejście na zaopatrzenie emerytalne (z 15 na 25 lat służby) oraz nałożono minimalny wiek przejścia na wcześniejszą emeryturę - 55 lat. Wyraźnie zmniejszyły się również zarobki w porównaniu do rynku pracy.

Dotychczasowe badania nad personelem więziennym koncentrowały się na funkcjonariuszach czynnych zawodowo, z różnym stażem i doświadczeniem zawodowym. Nie przeprowadzono analizy właściwości psychospołecznych kandydatów ani funkcjonariuszy, którzy dopiero rozpoczynają pracę w więziennictwie i tym samym ich nastawienie, motywacja, zaangażowanie, poglądy, opinie itp. nie są jeszcze zmienione pod wpływem zetknięcia się ze specyficzną organizacją instytucji penitencjarnej, starszych stażem i często wypalonych współpracowników czy porażkami wpisanymi w pracę więziennika. Jest to o tyle ważne, że wraz ze stażem pracy oraz nabywaniem doświadczenia zawodowego zmieniają się priorytety wpływające na motywację do pracy i zaangażowanie w wykonywanie codziennych obowiązków służbowych. Instytucja totalna i biurokratyczna, jaką jest więzienie, po pewnym czasie zmienia u funkcjonariuszy sposób postrzegania własnej osoby i osobistych celów przez pryzmat oficjalnej wizji i misji oraz celów instytucjonalnych systemu penitencjarnego, jak i nieformalnych celów wynikających z tak zwanego drugiego, sekretnego życia uczestników rzeczywistości więziennej. Uzasadnia to podjęcie badań nad czynnikami podjęcia decyzji o pracy w Służbie Więziennej mimo niekorzystnego obrazu więziennictwa w społeczeństwie, niebezpieczeństw pracy z przestępcami oraz relatywnie niskimi zarobkami i kurczącymi się w ostatnich latach przywilejami sektora mundurowego.

\section{Materiał i metoda badań}

Celem badań było poznanie motywów, jakimi kierują się kandydaci do pracy w więziennictwie, oraz określenie zróżnicowania motywacyjnego funkcjonariuszy przyjętych do pracy na starych i nowych zasadach emerytalnych. Do 2012 roku funkcjonariusze nabywali uprawnień emerytalnych - niezależnie od wieku - po 15 latach nieprzerwanej służby w więziennictwie lub innych formacjach mundurowych. Od 2013 roku zaczęła obowiązywać nowa ustawa

22 R. Poklek, Motywy podejmowania pracy przez szeregowych funkcjonariuszy Stużby Więziennej, [w:] Szeregowcy w grupach dyspozycyjnych. Socjologiczna analiza zawodu i jego roli w społeczeństwie, red. J. Maciejewski, A. Krasowska-Marut, A. Rusak, Wrocław 2009, s. 322 n.

${ }^{23}$ R. Poklek, Motywacja prospołeczna funkcjonariuszy Stużby Więziennej jako grupy zawodowej z misja społeczna, „Resocjalizacja Polska” 9, 2015, s. 159-177; https://www.researchgate.net/ publication/281094879_Motywacja_prospoleczna_funkcjonariuszy_Sluzby_Wieziennej_jako_grupy_zawodowej_z_misja_spoleczna (dostęp: 21.07.2019).

Forum Socjologiczne 10, 2020

(C) for this edition by CNS 
emerytalna w sektorze mundurowym, w której ustalono wiek emerytalny na 55 lat oraz staż służby na minimum 25 lat, co mogło mieć wpływ na stan motywacji podejmowania pracy w Służbie Więziennej. Główny problem badawczy przyjął zatem postać pytania: „Jakie kierunki motywacji prezentują funkcjonariusze nowo przyjęci do służby w więziennictwie?”. Próbowano również dociec odpowiedzi na pytanie szczegółowe: „Jakie różnice w zakresie motywacji występują u funkcjonariuszy przyjętych do służby w roku 2012 oraz roku 2017?”24.

Zmienną niezależną główną mierzoną w badaniu była motywacja zawodowa, a zmienną niezależną pośredniczącą mającą (zdaniem autora) wpływ na motywację i decyzję o podjęciu pracy w więziennictwie była data wstąpienia do służby. Zmienną zależną było podjęcie pracy w Służbie Więziennej.

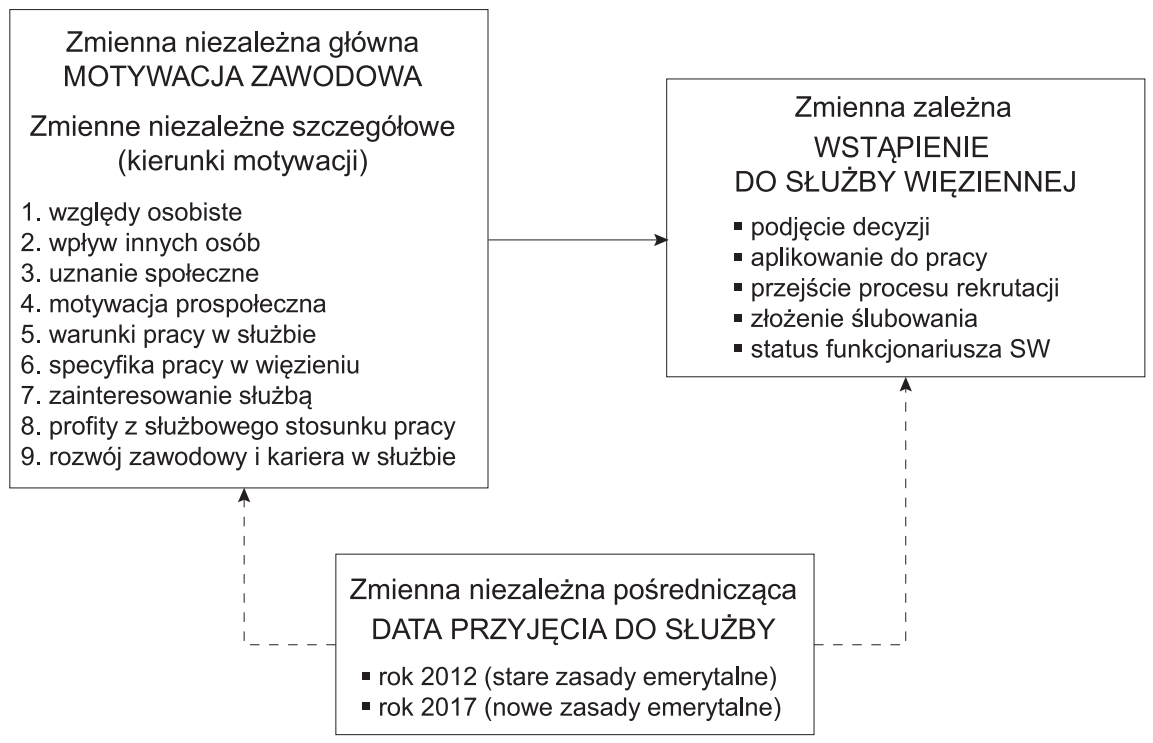

Rysunek 1. Zmienne analizowane w badaniu

Źródło: opracowanie własne.

W badaniach wykorzystano metodę badań testowych i skonstruowane do tego celu narzędzie w postaci kwestionariusza „Inwentarz podejmowania pracy w Służbie Więziennej”. Inwentarz pozwala oszacować natężenie motywacji zawodowej personelu więziennego. Składa się z 27 itemów (pytań/stwierdzeń), na które badani odpowiadają, określając poziom występowania u nich danego motywu szczegółowego na pięciostopniowej skali odpowiednio punktowanej: 0 - motyw nie występuje, 1 bardzo małe natężenie motywu, 2 - małe natężenie motywu, 3 - duże natężenie

${ }^{24} \mathrm{~W}$ niniejszym opracowaniu zaprezentowano tylko wycinek badań i najważniejsze pytania badawcze oraz wyniki. 
motywu, 4 - bardzo duże natężenie motywu. Oprócz określenia siły motywów szczegółowych za pomocą inwentarza, po zastosowaniu klucza obliczeniowego, można oszacować natężenie dziewięciu kierunków motywacji: 1. względy osobiste i życiowe, 2. wpływ innych osób, 3. uznanie społeczne, 4. motywacja prospołeczna, 5. warunki pracy w służbie, 6. specyfika pracy w więzieniu, 7. zainteresowania pracą w służbie więziennej, 8. profity z służbowego stosunku pracy, 9. rozwój zawodowy i kariera w służbie. Po zsumowaniu wyniki w poszczególnych skalach inwentarza (kierunkach motywacji) wahają się od 0 do 12 punktów, gdzie wynik 0-3 oznacza bardzo niskie natężenie motywu, 4-6 niskie, 7-9 wysokie, 10-12 bardzo wysokie natężenie motywu.

Badaniami objęto wszystkich funkcjonariuszy rozpoczynających służbę w roku 2012 oraz w roku 2017, którzy odbywali obowiązkowy kurs przygotowawczy w ośrodkach szkoleniowych Służby Więziennej. Ze względu na dobrowolność badania powrotność kwestionariuszy wyniosła około 50\%, a ostatecznie zebrano prawidłowo wypełnione 2063 kwestionariusze umożliwiające analizę statystyczną. Do oszacowania statystycznej istotności różnic pomiędzy badanymi grupami wykorzystano test $\mathrm{t}$, a jako poziom istotności, przy którym odrzucano hipotezę o braku różnic, przyjęto wartość $\alpha=0,05$.

\section{Prezentacja wyników badań}

Zdecydowana większość (7 spośród 9) kierunków motywacji zawodowej ogół badanych mieści się w granicach wyników wysokich (pomiędzy 6 a 8 punktów), tylko dwa kierunki - warunki pracy w więziennictwie oraz profity wynikające z służbowego stosunku pracy — plasują się na poziomie wyników niskich (pomiędzy 4 a 6 punktów). Oznacza to, że nowo przyjęci do służby funkcjonariusze charakteryzują się dużą motywacją gwarantującą pozytywne nastawienie do podjęcia trudów zawodu więziennika i zaangażowaniem w realizację zadań służbowych.

Tabela 1. Średnie (M), odchylenia standardowe (s) i współczynniki zmienności (V) wyników w skalach Inwentarza motywów podejmowania pracy w Służbie Więziennej

\begin{tabular}{|l|c|c|c|}
\hline \multicolumn{1}{|c|}{ Skala } & M & s & V \\
\hline warunki pracy w więziennictwie & 5,550 & 2,083 & 37,530 \\
\hline profity z służbowego stosunku pracy & 4,330 & 2,361 & 54,540 \\
\hline zainteresowanie pracą w Służbie Więziennej & 7,298 & 2,130 & 29,180 \\
\hline względy osobiste i życiowe & 6,744 & 2,316 & 34,345 \\
\hline motywacja prospołeczna & 7,763 & 1,890 & 24,343 \\
\hline specyfika pracy w więzieniu & 6,751 & 2,224 & 32,936 \\
\hline
\end{tabular}

Forum Socjologiczne 10, 2020

(C) for this edition by CNS 


\begin{tabular}{|l|c|c|c|}
\hline wpływ innych & 7,873 & 2,250 & 28,581 \\
\hline rozwój zawodowy i kariera w służbie & 7,177 & 1,575 & 21,948 \\
\hline uznanie społeczne & 7,943 & 2,058 & 25,907 \\
\hline
\end{tabular}

Źródło: opracowanie własne $(\mathrm{n}=2063)$.

Dominującym kierunkiem motywacji jest uznanie społeczne. Oznacza to, że decyzji badanych o przyjęciu się do pracy w więziennictwie towarzyszyło poczucie prestiżu służby, szacunku i uznania społecznego, mieli oni pozytywny wizerunek formacji oraz poczucie ważności służby i obywatelskiej pracy dla społeczeństwa. Stosunkowo wysokie wskaźniki mają także kierunki związane $\mathrm{z}$ wpływem innych osób i motywacją prospołeczną. Ważnym motywem wstąpienia w szeregi Służby Więziennej była zatem namowa kolegów i znajomych, sytuacja materialna rodziny, a być może i poparcie osób pracujących w służbie. Dość istotną rolę w zatrudnieniu w więziennictwie odgrywało poczucie misji do spełnienia i chęć walki z patologią społeczną, wiara w resocjalizację, możliwość pomocy i poprawiania więźniów oraz świadomość służby społeczeństwu związanej z zapewnieniem bezpieczeństwa publicznego i praworządności w państwie. $\mathrm{W}$ przeciwieństwie do dotychczasowych doniesień $\mathrm{w}$ literaturze przedmiotu badani funkcjonariusze wykazują najniższy poziom motywacji materialnej. Nie miały dla nich tak dużego znaczenia profity związane z wcześniejszą emeryturą i dodatkami finansowymi przynależnymi funkcjonariuszom sektora mundurowego czy motywacja związana z warunkami pracy, czyli przekonanie o wysokich zarobkach, stałości dochodów i pewności wypłaty oraz stabilności pracy w więziennictwie jako jednostce budżetowej.

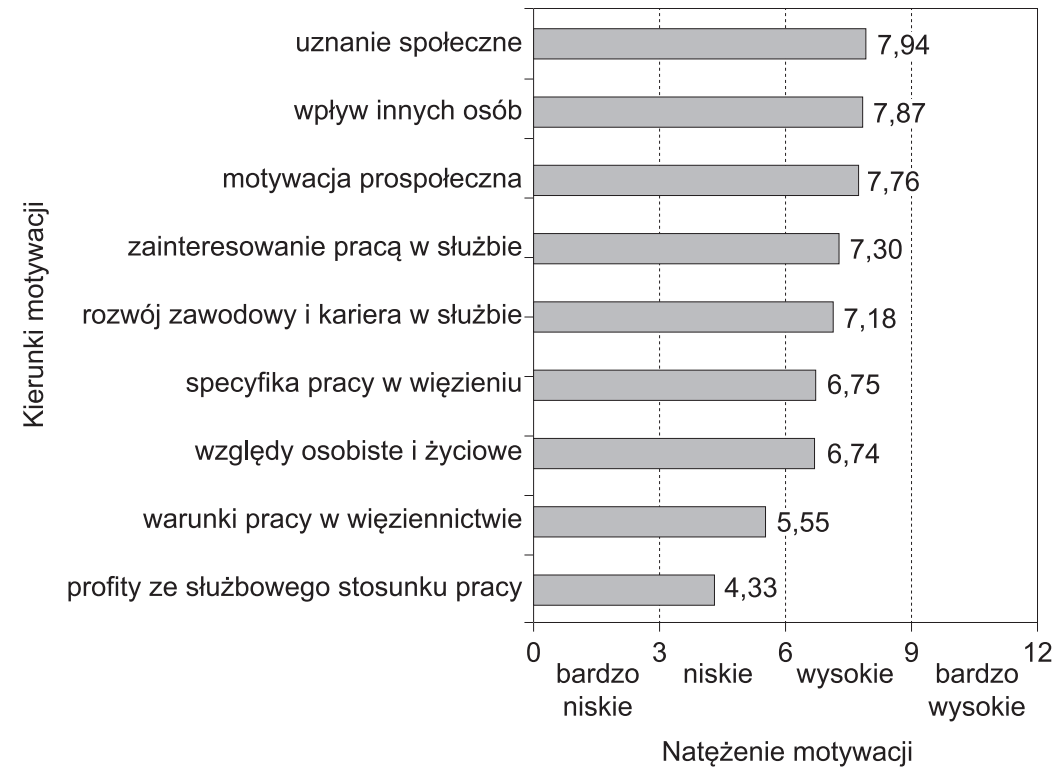

Wykres 1. Natężenie kierunków motywacji zawodowej badanych

Źródło: opracowanie własne $(\mathrm{n}=2063)$.

Forum Socjologiczne 10, 2020

(C) for this edition by CNS 
Przeprowadzenie badań tym samym narzędziem dwóch grup w odstępie 5 lat pozwala przybliżyć zmiany w strukturze motywacyjnej nowoprzyjętych funkcjonariuszy. W tym okresie, po pierwsze, nastąpiły zmiany w systemie emerytalnym służb mundurowych, zamrożone były również podwyżki dla funkcjonariuszy Służby Więziennej, podczas gdy wcześniej - co roku - ich wynagrodzenie było waloryzowane. Zmieniła się również sytuacja na rynku pracy. Wcześniej, z uwagi na bezrobocie, służba w więziennictwie była atrakcyjną pracą w sektorze budżetowym, stanowiła stabilne miejsce zatrudnienia z pewną wypłatą. Aktualnie Służba Więzienna nie jest już tak popularnym pracodawcą. Doszło do tego, że w niektórych okręgach poszukiwane są osoby chętne $-\mathrm{z}$ uwagi na niedobory kadrowe spowodowane odejściami na emeryturę i powstałe wakaty w jednostkach penitencjarnych.

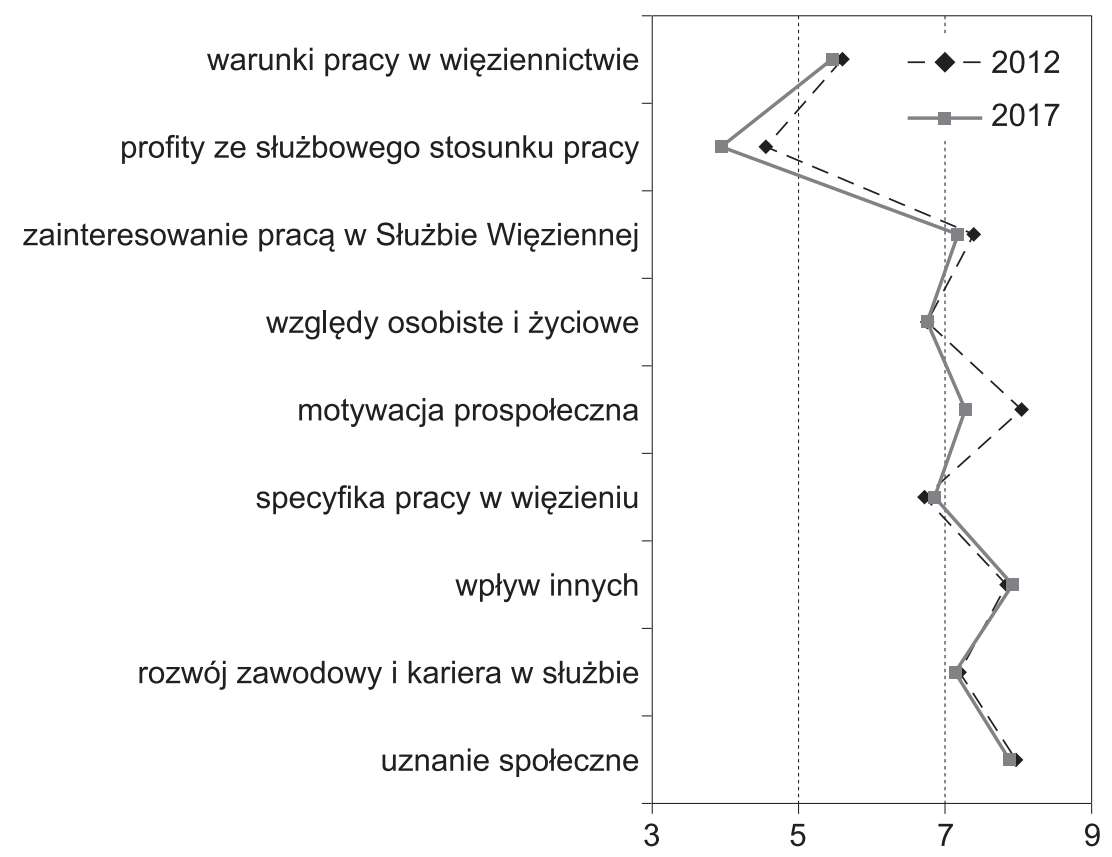

Wykres 2. Zróżnicowanie natężenia kierunków motywacji zawodowej w zależności od daty przyjęcia badanych do pracy w więziennictwie

Źródło: opracowanie własne $\left(\mathrm{n}_{2012}=1299, \mathrm{n}_{2017}=764\right)$.

Analizując uzyskane rezultaty, można stwierdzić, że funkcjonariusze podejmujący pracę w Służbie Więziennej w roku 2017 charakteryzują się niższym poziomem motywacji w porównaniu z funkcjonariuszami przyjętymi w roku 2012. Szczególnie jest to uwidocznione w skali „Profity z służbowego stosunku pracy”, co jest zrozumiałe ze względu na wprowadzone ograniczenia systemowe w tym zakresie. Charakteryzują się także zdecydowanie niższym poziomem motywacji prospołecznej. Szczegóły analizy statystycznej zaprezentowane są w tabeli nr 2. 
Tabela 2. Zróżnicowanie średnich wyników w skalach Inwentarza motywów podjęcia pracy w Służbie Więziennej w zależności od daty badania

\begin{tabular}{|l|c|c|c|c|c|c|}
\hline \multicolumn{1}{|c|}{ Skala } & $\mathrm{M}_{2012}$ & $\mathrm{~s}_{2012}$ & $\mathrm{M}_{2017}$ & $\mathrm{~s}_{2017}$ & $\mathrm{t}$ & $\mathrm{p}$ \\
\hline warunki pracy w więziennictwie & 5,603 & 2,086 & 5,461 & 2,076 & 1,496 & 0,135 \\
\hline profity z służbowego stosunku pracy & 4,562 & 2,339 & 3,935 & 2,349 & 5,875 & 0,000 \\
\hline $\begin{array}{l}\text { zainteresowanie pracą w Służbie } \\
\text { Więziennej }\end{array}$ & 7,384 & 2,129 & 7,152 & 2,124 & 2,395 & 0,017 \\
\hline względy osobiste i życiowe & 6,736 & 2,346 & 6,757 & 2,266 & $-0,195$ & 0,845 \\
\hline motywacja prospołeczna & 8,053 & 1,754 & 7,271 & 2,009 & 9,262 & 0,000 \\
\hline specyfika pracy w więzieniu & 6,723 & 2,220 & 6,800 & 2,231 & $-0,758$ & 0,448 \\
\hline wpływ innych & 7,857 & 2,252 & 7,901 & 2,248 & $-0,426$ & 0,670 \\
\hline rozwój zawodowy i kariera w służbie & 7,199 & 1,555 & 7,139 & 1,610 & 0,844 & 0,399 \\
\hline uznanie społeczne & 7,969 & 2,022 & 7,898 & 2,117 & 0,760 & 0,447 \\
\hline
\end{tabular}

Oznaczenia: $\mathrm{M}$ - średnia arytmetyczna, $\mathrm{s}$ - odchylenie standardowe, $\mathrm{t}-$ statystyka $\mathrm{t}_{d f=206_{1}}, \mathrm{p}-$ poziom istotności

Źródło: opracowanie własne $\left(\mathrm{n}_{2012}=1299, \mathrm{n}_{2017}=764\right)$.

Funkcjonariusze przyjęci do służby w roku 2012 różnią się pod względem statystycznym od przyjętych w 2017 roku w zakresie 3 spośród 9 analizowanych kierunków motywacji. Charakteryzuje ich wyższy średni poziom motywacji prospołecznej — znacznie częściej przejawiali poczucie misji do spełnienia i chęć walki z patologią społeczną, wiara w resocjalizację, możliwość pomocy i poprawiania więźniów oraz świadomość służby społeczeństwu związanej z zapewnieniem bezpieczeństwa publicznego i praworządności w państwie. Wykazują wyższy poziom motywacji związanej z profitami wynikającymi z ewentualnej możliwości odejścia na wcześniejszą emeryturę, dodatkami finansowymi, to jest ekwiwalent za sorty mundurowe, dodatki za brak mieszkania, nagrody resortowe oraz opieka socjalna nad funkcjonariuszami. Podjęcie pracy w roku 2012 częściej podyktowane było zainteresowaniem pracą $\mathrm{w}$ formacji paramilitarnej i wymagającej noszenia munduru, zainteresowanie resocjalizacją, kryminologią i prawem oraz poczucie patriotyzmu i dumy z noszenia munduru. Pozostałe wyniki są nieistotne statystycznie.

\section{Podsumowanie}

Zaprezentowanie w niniejszym opracowaniu rezultaty badań nad przyczynami podejmowania pracy w Służbie Więziennej rzucają nowe światło na strukturę motywacji zawodowej personelu więziennego. $\mathrm{W}$ dotychczasowych wynikach 
badań czynnych zawodowo funkcjonariuszy akcentowano ekonomiczne czynniki determinujące ich wybór zawodu ${ }^{25}$, a nieco niższy poziom motywacji prospołecznej. Wskazywano wówczas, że prymarne są motywy materialno-bytowe, stabilizacja zawodowa i możliwość odejścia na wcześniejszą emeryturę ${ }^{26}$. Zbieżności - poza motywami materialnymi - prezentowanych w niniejszym opracowaniu wyników z doniesieniami w literaturze dotyczą także zainteresowania charakterem pracy, zamiłowania do munduru, tradycji rodzinnych ${ }^{27}$, ciekawości i chęci sprawdzenia się $\mathrm{w}$ trudnych warunkach ${ }^{28}$, pozytywnego wizerunku formacji i uznania społecznego ${ }^{29}$.

Udzielając odpowiedzi na pytania postawione przed badaniami, można sformułować następujące wnioski:

1. Funkcjonariusze rozpoczynający pracę $\mathrm{w}$ więziennictwie charakteryzują się wysokim natężeniem większości kierunków motywacji, co może przełożyć się na zaangażowanie $\mathrm{w}$ realizację obowiązków oraz utożsamianie się z rolą zawodową więziennika.

2. Przeważąą̧cym kierunkiem motywacji zawodowej nowo przyjętych funkcjonariuszy Służby Więziennej jest uznanie społeczne dla Służby Więziennej. Wysoko usytuowane są motywy społeczne związane $\mathrm{z}$ wpływem innych osób (znajomych, rodziny) oraz motywacja prospołeczna związana z chęcią niesienia pomocy i poczuciem misji, co jest dobrym predykatorem ich identyfikacji z misją i zadaniami Służby Więziennej.

3. Funkcjonariusze podejmujący służbę w roku 2012 wykazują wyższy poziom motywacji zawodowej, a w szczególności w zakresie motywacji prospołecznej oraz profitów funkcyjnych; są również bardziej zainteresowani pracą w więziennictwie.

Ponieważ istnieje związek motywacji zawodowej z zaangażowaniem organizacyjnym, utożsamianiem się z rolą zawodową, efektywnością realizacji zadań służbowych itp., należy monitorować strukturę motywacyjną funkcjonariuszy i badać na różnych etapach ich kariery zawodowej. Rozbieżności między oczekiwaniami a rzeczywistością mogą skutkować obniżeniem motywacji i radykalnymi zmianami jej kierunków, co z kolei może przyczynić się do niedopasowania organizacyjnego, szybszego wypalenia zawodowego i utraty zaangażowania w pracę. Polityka kadrowa w formacji mundurowej i grupie dyspozycyjnej, jaką jest Służba

25 R. Poklek, Czynniki ekonomiczne jako motywy wyboru pracy w grupie dyspozycyjno-mundurowej na przykładzie Stużby Więziennej, [w:] Stratyfikacja w grupach dyspozycyjnych - socjologiczne azymuty badawcze, red. J. Maciejewski et al., Wrocław 2012, s. 53.

26 Por. H. Machel, Psychospołeczne uwarunkowania pracy resocjalizacyjnej personelu więziennego, Gdańsk 2001, s. 2017-2018.

27 Por. J. Nawój, Niektóre zagadnienia doboru do roli zawodowej funkcjonariusza więziennego i kierowanie jego rozwojem, [w:] Nabór i szkolenie funkcjonariuszy Stużby Więziennej w polskim systemie penitencjarnym. Diagnoza, ocena, prognoza, Kalisz 1995, s. 52.

${ }^{28} \mathrm{H}$. Machel, op. cit.

${ }^{29}$ R. Poklek, Społeczne determinanty podejmowania pracy w służbie więziennej, [w:] Rekrutacja do grup dyspozycyjnych - socjologiczna analiza problemu, red. J. Maciejewski, Wrocław 2011, s. 506 n. 
Więzienna, nie może obejść się bez uwzględnienia systemu motywacyjnego w zarządzaniu zasobami ludzkimi.

\section{Bibliografia}

\section{Litertura}

Badanie opinii publicznej na temat wizerunku wymiaru sprawiedliwości, oceny reformy wymiaru sprawiedliwości, aktualnego stanu świadomości w zakresie alternatywnych sposobów rozwiazywania sporów oraz praw osób pokrzywdzonych przestęsstwem. Raport z badań, IBC Group \& Homo Homini, Warszawa, luty 2009, s. 15 n.

Goffman E., Instytucje totalne. O pacjentach szpitali psychiatrycznych i mieszkańcach innych instytucji totalnych, Sopot 2011.

Grzesia S., Biurokracja i biurokratyzacja w pracy penitencjarnej wychowawców, [w:] Blaski i cienie współczesnej przestrzeni penitencjarnej. Człowiek a system, red. P. Stępniak, Kalisz 2014.

Jędrzejak K., Konflikty w izolacji więziennej, [w:] Problemy więziennictwa u progu XXI wieku, red. B. Hołyst, S. Redo, Warszawa-Wiedeń-Kalisz 1996.

Krukowski A., Socjologia zakładu karnego (podstawowe zagadnienia), [w:] Problemy współczesnej penitencjarystyki w Polsce, red. B. Hołyst, Warszawa 1984.

Machel H., Psychospołeczne uwarunkowania pracy resocjalizacyjnej personelu więziennego, Gdańsk 2001.

Nawój J., Niektóre zagadnienia doboru do roli zawodowej funkcjonariusza więziennego i kierowanie jego rozwojem, [w:] Nabór i szkolenie funkcjonariuszy Stużby Więziennej w polskim systemie penitencjarnym. Diagnoza, ocena, prognoza, Kalisz 1995.

Piotrowski A., Medialny wizerunek Stużby Więziennej, „Przegląd Więziennictwa Polskiego” 2010.

Poklek R., Czynniki ekonomiczne jako motywy wyboru pracy w grupie dyspozycyjno-mundurowej na przykładzie Stużby Więziennej, [w:] Stratyfikacja w grupach dyspozycyjnych - socjologiczne azymuty badawcze, red. J. Maciejewski, W. Forysiak, Z. Kuźniar, B. Stasiaczyk, Wrocław 2012.

Poklek R., Instytucjonalne i psychospołeczne aspekty więzienia, Kalisz 2010.

Poklek R., Misja i zadania Stużby Więziennej a jej wizerunek i prestiż w społeczeństwie, [w:] Grupy dyspozycyjne wobec zagrożeń bezpieczeństwa państwa, red. J. Maciejewski, M. Stochmal, Z. Ludziejewski, Wrocław 2016.

Poklek R., Motywacja do pracy i doskonalenia zawodowego personelu więziennego w ujęciu dwuczynnikowej koncepcji motywacji-higieny F.I. Herzberga, Kalisz 2012.

Poklek R., Motywacja osiagnięć funkcjonariuszy Stużby Więziennej, Kalisz 2015.

Poklek R., Motywacja prospołeczna funkcjonariuszy Stużby Więziennej jako grupy zawodowej z misja społeczna, „Resocjalizacja Polska” 9, 2015.

Poklek R., Motywy podejmowania pracy przez szeregowych funkcjonariuszy Stużby Więziennej, [w:] Szeregowcy $w$ grupach dyspozycyjnych. Socjologiczna analiza zawodu i jego roli w społeczeństwie, red. J. Maciejewski, A. Krasowska-Marut, A. Rusak, Wrocław 2009.

Poklek R., Stużba Więzienna w systemie bezpieczeństwa państwa, „Securitologia” 2013, nr 1 (17).

Poklek R., Społeczne determinanty podejmowania pracy w służbie więziennej, [w:] Rekrutacja do grup dyspozycyjnych - socjologiczna analiza problemu, red. J. Maciejewski, Wrocław 2011.

Poklek R., Piotrowski A., Stres zawodowy personelu więziennego pionu ochronnego i wychowawczego, [w:] Metodologiczne problemy w badaniach grup dyspozycyjnych, red. J. Maciejewski, M. Stochmal, Wrocław 2014.

Przybyliński S., Podkultura więzienna. Wielowymiarowość rzeczywistości penitencjarnej, Kraków 2005.

Siemaszko A., Gruszczyńska B., Marczewski M., Ostaszewski P., Społeczna percepcja zagrożeń korupcyjnych $w$ Polsce, [w:] Korupcja i antykorupcja. Wybrane zagadnienia. cz. 3, red. J. Kosiński, K. Krak, A. Koman, Warszawa 2012.

Forum Socjologiczne 10, 2020

(C) for this edition by CNS 
Sztompka P., Socjologia. Analiza społeczeństwa, Kraków 2007.

Turner J.H., Socjologia: koncepcje i ich zastosowanie, Poznań 1998.

Urbanowicz L., Wizerunek służby więziennej w środkach masowego przekazu, [w:] Stużba więzienna wobec problemów resocjalizacji penitencjarnej, red. W. Ambrozik, P. Stępniak, Poznań-Warszawa-Kalisz 2004.

\section{Źródła internetowe}

Kolejne samobójstwo więźnia w Białołęce. Powód - zespół abstynencyjny, https://www.tvp.info/33647434/ kolejne-samobojstwo-wieznia-w-bialolece-powod-zespol-abstynencyjny (dostęp: 21.07.2019).

Morderstwo na przepustce z więzienia. Nie żyje kobieta i dziecko, https://www.tvp.info/38913425/morderstwo-na-przepustce-z-wiezienia-nie-zyje-kobieta-i-dziecko (dostęp: 21.07.2019).

Roczna informacja statystyczna za rok 2018, Ministerstwo Sprawiedliwości, Centralny Zarząd Służby Więziennej, https://sw.gov.pl/strona/statystyka-roczna (dostęp: 26.01.2020).

Uciekinier z pomorskiego więzienia zatrzymany w Szczecinie, https://www.fakt.pl/wydarzenia/polska/ trojmiasto/39-latek-uciekl-z-wiezienia-w-czarnem-zatrzymano-go-w-szczecinie/7f6l5j6 (dostęp: 21.07.2019).

\section{Professional motivation of officers starting work in prison}

\section{Summary}

The Prison Service is a disposable group, and the occupation of a prison officer is burdened with many difficulties resulting from the specificity of the institution's environment, threats from prisoners, the job's lowly-perceived prestige and lack of respect from the wider society. This raises the question of what motivations are guided by those who make the decision to join the service and to become involved in the prison system. The study presents the author's own research on the structure of professional motivation conducted among newly- qualified officers in 2012 and 2017. In addition to the analysis of the intensity of motivation directions, comparisons were made between groups of officers adopted in 2012 and 2017, taking into account socio-economic changes occurring within five years, and especially changes to the pension act of officers in the uniformed services.

Keywords: Prison Service, dispositional and uniform groups, motivation, professional motivation, inventory of motives for taking up employment 